\title{
Article \\ The Impact of the Multicultural Education on Students' Attitudes in Business Higher Education Institutions
}

\author{
Peter Karacsony ${ }^{1} \mathbb{1}$, Vivien Pásztóová ${ }^{1}{ }^{\mathbb{D}}$, Mikhail Vinichenko ${ }^{2}$ and Peter Huszka ${ }^{3, *}$ \\ 1 Faculty of Economics, and Informatics, J. Selye University, 94501 Komárno, Slovakia; \\ karacsonyp@ujs.sk (P.K.); vivien.pasztoova97@gmail.com (V.P.) \\ 2 Faculty of Management, Russian State Social University, 129226 Moscow, Russia; mih-vas2006@yandex.ru \\ 3 Faculty of Economics, Széchenyi István University, 9026 Győr, Hungary \\ * Correspondence: huszkap@sze.hu
}

check for updates

Citation: Karacsony, P.; Pásztóová, V.; Vinichenko, M.; Huszka, P. The Impact of the Multicultural Education on Students' Attitudes in Business Higher Education Institutions. Educ. Sci. 2022, 12, 173. https://doi.org/10.3390/ educsci12030173

Academic Editors: Rabindra Nepal, James Albright and Han Reichgelt

Received: 13 December 2021 Accepted: 28 February 2022 Published: 2 March 2022

Publisher's Note: MDPI stays neutral with regard to jurisdictional claims in published maps and institutional affiliations.

Copyright: (c) 2022 by the authors. Licensee MDPI, Basel, Switzerland. This article is an open access article distributed under the terms and conditions of the Creative Commons Attribution (CC BY) license (https:// creativecommons.org/licenses/by/ $4.0 /)$.

\begin{abstract}
The research aims to assess the cultural diversity of international students studying in higher education institutions. The results of the research provide an overview of the attitude of students studying in institutions of higher education to learning, the factors influencing their studies, and their expectations for their studies abroad. One type of quantitative research method, the questionnaire, was chosen for the primary research. The research results reflect the perspectives of students from different cultural backgrounds in institutions of higher education and focus on the phenomena and situations they experience. Following the hypothesis test results, an outcome can be seen that students believe that their studies in higher education provide a good foundation for their personal development. The results also confirmed that learning in a multicultural environment could positively affect students' working abilities.
\end{abstract}

Keywords: culture; cultural diversity; multiculturalism; student; higher education

\section{Introduction}

Today, the fully globalized world requires increased labor demand due to cultural diversity and the inclusion of prominent students from different cultural backgrounds in education [1]. Qualifications and values acquired in higher education can increasingly be mentioned in favour of representing a prosperous life, a series of public, scientific, and intellectual actions, and versatility [2]. The spectrum of education in a culturally diverse environment has regularly expanded its accessibility, having not been limited to ethnic differences [3]. Culture has many interpretations, a term that describes the lifestyle of human communities. It is, in fact, a learning process in which one learns to live and survive in a social environment and to interpret one's emotions towards others [4]. Culture includes individuals and groups' attitudes, mentalities, and beliefs with common historical roots and geographically exact locations, the value system and knowledge they represent, and the habits that characterize them [5].

In contrast, there are also material, i.e., substantial, elements of a culture where it is essential to mention education, which can be both a physical and a spiritual value [6]. Education is a conscious and voluntary process of culture [7]. In Rosado's (1996) formulation, multiculturalism means orientation towards the future. Multiculturalism is a phenomenon that recognizes cultural differences in society and encourages cooperation between individuals from different cultures [8]. Byker \& Marquardt [9] mentions Rosado's (1996) work in interpreting multiculturalism as a structure based on an internal belief that values and respects the socio-cultural values of all existing cultural communities. Multiculturalism is an idea that combines equal opportunities and cultural diversity, which encourages the appreciation of all kinds of people [10].

The birth of multicultural education is linked to the movements of civil rights in the 1960s, where education was still a privileged thing. At that time, women, people with 
disabilities, and members of other cultural communities, who dropped out of education, wanted to continue their education [11]. Multicultural education is, in fact, an endeavor to remodel traditional education, as a consequence of which development is a carefully considered and socially prepared personality [12]. Multicultural education is an educational concept of which primary goal is to raise the educational structure onto a level where everyone has equal opportunities in terms of education [13]. Tonbuloglu et al. [14] argues that a holistic process involving educational institutions does not accept students separation and fully supports social and cultural diversity. Developing a multicultural perspective and encouraging people to think requires cognitive education that enhances caring for others [15]. In the context of this significant transformation, it is crucial to develop a curriculum and tactical plan to be used in education, and educators, students themselves, and their families also have an essential role to play [16]. Educators' mentality and perceptions of multiculturalism play an essential role in educating and motivating students [17]. Educators express human and empathetic behavior in multicultural education, setting up an example for students [18]. In multicultural education, it is crucial that students feel like equal group members [19].

Multicultural education does not only include the education of students for cultural diversity and the education of children of different ethnicities but goes far beyond this, as it shapes the institution's image and seeks to meet the broadest possible range of needs [20]. A functional relationship between the teacher and the student and the proper curriculum design are essential elements for an effective educational process [21]. Educators in such a university atmosphere must possess specific competencies, such as supportive spirit, flexibility, and an empathic vision, which are essential in teaching in a multicultural environment [22]. Multicultural education fosters understanding and humane social cooperation; the primary purpose is to convey reactions related to personal culture and explore different lifestyles [23].

The spectrum of cultural diversity is already an entirely natural phenomenon in the labor market and the education system [24,25]. Ethnics and communities representing different cultural traits meet in the context of work and appear within the walls of educational institutions [26]. Since the encounter and clash of cultures is not always a cloudless and problem-free process, it is essential to address each other with understanding and appreciation. The present study focuses on the international students in higher education and explores their learning attitudes, factors influencing their studies, and their perceived thoughts about their studies.

\section{Literature Review}

The processes of universalization set forward an unlimited number of cultural changes, of which positive consequence is the improving of standard of living and increasing and broadening the interest in recent ideas [27]. One of the most popular reforms in higher education today is the internationalization of higher education, which is undergoing a regular transformation [28]. During internationalization, the goal is to incorporate and implementation of cross-cultural and inter-ethnic expansion into higher education practices [29]. Internationalization is compatible with the deepening of experience gained during studies and the acquisition of work-related competencies in the future, which will also expand the opportunities of career development for students [30]. In terms of academic mobility, the student base considering Hungary as a destination country is becoming more and more widespread in higher education [31]. Students in higher education can obtain a degree in a home environment and pursue their goals in other foreign countries. Most students from abroad participate in full-time, undergraduate training [32]. Therefore, higher education must contribute to enriching knowledge, socio-cultural development, and mobility between societies [33]. Although multicultural education is reported in several kinds of literature, the current research topic is still considered untapped in some respects [34]. Primary studies of culturally diverse education reflect that the integration of this issue into education was initially minor [35]. Extensive educational practices provide a supportive and context-based 
educational routine that emphasizes the educational operations of everyone [36]. The basis of multiculturalism is linked to the concept of highly diverse culture, according to which it covers a worldview that is designed to promote the development of society. A psychological approach is suitable for accepting an accurate self-image and expressing a sense of dignity arising from the consciousness of individual identity [37]. Multiculturalism as a concept refers to the culturally diverse attitudes of the social environment that surrounds and characterizes people and the linguistics, religion, ethnics, and many other aspects of diversity [38]. Findings of existing research outline that multicultural education contributes to multicultural awareness and skills [35]. Some argue that integration of diversity into education provides a higher learning value, acting as an accelerant to provide a more meaningful educational medium [39]. These educational institutions can be seen as an arena for building relationships between young people, wherein in many cases, students from other cultures interact with each other [40]. According to experts, accumulated multicultural awareness promotes opportunities and achievements for students with different cultural backgrounds, for which minimizing social depths and creating a positive teacher-student relationship is a crucial factor [41]. Through multicultural education, the student is attuned to the diversity of society. Educational institutions and their educators must encourage inclusion in a spirit of diversity [42]. Multicultural education is a complex form of education that targets to meet the needs and wants related to the intellectual development of people from different cultures and communities [43]. In addition, it plays a role in developing young people's identity, and their orientation and skills reinforce their independent adult life [44]. Multicultural education has a significant and positive impact on society. Different students who have studied in a multicultural environment are more likely to work together in the future [45]. In addition, multicultural education promotes a sense of democracy and the foundations of social peace $[46,47]$. Internationalization in higher education continues to be very popular worldwide [48]. Universities that have become international must help students' integration into the academic life of unprecedented linguistic, cultural, and experiential diversity and must prepare them for life after graduation, both in the workplace and in the social contexts. It is, therefore, the duty of universities to actively develop the necessary intercultural skills of students [49].

Banks stressed the importance of the five dimensions of multicultural education to enhance knowledge and educate students for inclusion and empathy and the teachers' cultural readiness, listing various theoretical and practical examples. Furthermore, it is essential to describe the central terms, make education understandable to all, to acquire a positive attitude towards others, and to consolidate the social and educational culture. He believes that these factors need to be validated simultaneously [50]. Cultural diversity offers many opportunities and significant challenges for the students involved. The biggest challenge in educating students from different cultural backgrounds is the proper coordination of different lifestyles, unique characteristics of national mentality, and educational habits [51]. A culturally diverse educational environment prepares the individual to adapt to the diverse society [52]. As a result of globalization, recent university graduates need to have more than just professional competencies when entering the labor market. The open worldview and the tendency to build international relations are essential [53]. According to this view, it is essential to emphasize professional cooperation between cultures. Working together leads to the business and educational environment [10,54].

In the light of these studies, we have formulated our first hypothesis:

H1: As for female and male students, their multicultural studies are a good foundation for starting their work.

H0: As for female and male students, their multicultural studies are not reasonable for starting their work.

Coordinating educational practice and curriculum is essential for multicultural education. In higher education, educational practices ensure the transfer of a wide range of knowledge and experience that contributes to academic and professional progress and the 
personal development of individuals [55]. In multicultural education, students are enriched with skills that allow them to benefit from talking with people from other cultures, both professionally and privately [56,57].

Based on these studies, we formulated our second hypothesis:

H2: As for female and male students, their multicultural studies provide a good foundation for personal development.

H0: As for female and male students, their multicultural studies do not provide a reasonable basis for their personal development.

\section{Materials and Methods}

In the first step, the research focuses on the collection and interpretaion of secondary information. Next, we based our research on relevant literature, thus clarifying the research objectives and formulating the hypotheses to be examined based on the literature review.

To collect the primary data of our research, we chose one of the types of quantitative researching methods, the questionnaire researching technique. The questionnaire researching procedure is a standard data collection technique that collects data from potential respondents related to a questionnaire having been designed according to the research objectives and hypotheses. The questionnaire research method has proved to be an appropriate solution, as our data collection occurred during the global outbreak of COVID-19, while attendance education was discontinued. Data collection began in late March 2021 and ended in August 2021. The questionnaires were compiled and sent out electronically, considering the security measures introduced due to the pandemic and the respondents health. The questionnaire was prepared in English to reach the broadest possible base of respondents and to avoid language barriers. A total of 19 questions were formulated in the questionnaire. The survey was conducted at several universities and students from different cultural communities and nationalities. The questionnaire survey was implemented at different Hungarian universities, which provide education for international students in terms of various mobility programs. Therefore, we processed students' responses from three continents (Europe, Africa, Asia). In the case of anonymous survey, we only found out a few general demographics of the respondents. Such data included the gender, age, and the nationality of respondents. In addition, three questions were related to respondents studies and surveyed their experience in the labor market.

The second part of the questionnaire discussed the central theme of research, multicultural education. To achieve and implement results and helpful information to others, we used a Likert-scale solution from 1 to 10 to sort individual preferences. First, the data was filtered and compressed and sorted into a database. Then, we used a program suitable for SPSS statistical analysis to evaluate the data, perform the individual calculations, and test our hypotheses. Finally, the obtained results were presented by tables using the spreadsheet function of Microsoft Word. In connection with testing the hypotheses, we examine the impact of the experience and knowledge gained in higher education on the contribution of starting work and personal development in terms of gender roles. For this reason, a one-way analysis of variance was performed, using ANOVA analysis along with the gender as a factor.

\section{Results}

\subsection{Description of the Sample}

Table 1 shows the demographics of the research. In connection with the analysis of the research results, we worked with $\mathrm{N}=282$ sample numbers. As a result, we could draw varied and valuable results and conclusions. For example, $65.2 \%$ of the respondents are women, and $34.8 \%$ are men. In terms of the continuous variety of age, $32.6 \%$ of the respondents were 20 years old (92 people), the minimum age was $18(6 \%)$, and the maximum age was $42(0.4 \%)$. Regarding the demographic data, it was found that undergraduate students completed $53.9 \%$ of the questionnaire, and $79.1 \%$ of the respondents studied 
economics. As for the aspect of nationality, we formed three main groups. The first group included 153 students of European nationality. The second group had 82 Asian students, and the third consisted of 47 African students.

Table 1. Demographic data.

\begin{tabular}{cccc}
\hline N Total & 284 & & \\
\hline Sex & Women (65.2\%) & Men (34.8\%) & maximum age 42 \\
Age group & $32.6 \%$ 20 years old & minimum age 18 & $(0.4 \%)$ \\
Grade & $(92$ people) & $(6 \%)$ & \\
Study program & Undergraduate & \\
Source: Questionnaire research based on own editing.
\end{tabular}

Before applying for higher education, $75.2 \%$ of the respondents had already gained experience in the labor market. $47.9 \%$ of the respondents had smaller jobs for less than a year and less than $20 \mathrm{~h}$ a week. $20.2 \%$ of the respondents had a regularly paid job for at least a year and $20 \mathrm{~h}$ a week. $7.1 \%$ of the respondents completed a trainee status via professional course, and $24.8 \%$ have no experience in the labor market. We perform a Chi-square test for the variant being dependent on the experience in labor market, and for the variant being independent on the field of studies. The Chi-square test can be used to show and verify that the variants to be tested are independent of each other. During the statistical test, we worked with $\mathrm{N}=282$ sample numbers. There is a significant correlation between the two variants such as $0.03<0.05$. The Chi-square value is 31.27 , the degree of alteration $(\mathrm{df})=18$. The degree of alteration is the factor that determines the value of the Chi-square. Based on the statistical test, it can be concluded that the experience gained in the labor market before starting the studies does not influence the choice of the field of training. The statistical test is illustrated in Table 2.

Table 2. Chi Square Test for the experience in the labor market and for the field of study.

\begin{tabular}{cccc}
\hline & Value & df & Asymptotic Sig. (2-Tailed) \\
\hline Pearson Chi-Square & 31.27 & 18 & 0.03 \\
Likelihood Ratio & 32.86 & 18 & 0.02 \\
Linear-by-linear Association & 0.18 & 1 & 0.68 \\
N of Valid Cases & 282 & & \\
\hline
\end{tabular}

Source: SPSS database.

\subsection{Results}

During the research, we considered it essential to estimate to which extent would the influencing factors having been formulated by us affect the studies of university students. Respondents were able to form their opinions on a Likert scale ranging from 1 to 10 . Each result is illustrated in Table 3, according to which flexible timetable (33\%), stress (21.6\%), and personal development (31.9\%) were considered the essential factors rated for the highest number. In addition, the harmonious atmosphere $(24.5 \%)$, the new challenges (25.2\%), the conflict situation $(18.4 \%)$, the complexity of the task to be solved (19.9\%), the strict teacher $(19.9 \%)$, and the system of requirements $(22.3 \%)$ are also significant. In the case of the exemplary teacher, we received a similar assessment twice. For scale-type questions, it is possible to examine the Cronbach's alpha coefficient, a reliability indicator that measures internal consistency. However, the appropriate value is between 0.70 and 0.85 , but it must reach the minimum level of 0.60 . For the ten influencing elements examined in our case, the Cronbach's alpha coefficient is 0.87 , so it exceeds the limit by 0.2 , which means that the scale is indicating correctly. 
Table 3. Which factors are influencing your studies? (Please rate on a scale of 1 to 10, 1-least affecting, 10-influence the most).

\begin{tabular}{cc}
\hline & Frequency/Percent \\
\hline Flexible timetable & $10(33 \%)$ \\
Personal development & $10(31.9 \%)$ \\
New challenges & $8(25.2 \%)$ \\
Harmonious atmosphere & $8(24.5 \%)$ \\
Exemplary teacher & $7(21.3 \%)$ \\
Stress & $10(21.6 \%)$ \\
Conflict situation & $8(18.4 \%)$ \\
Complexity of the tasks to be solved & $8(19.9 \%)$ \\
Requirement system & $8(22.3 \%)$ \\
Strict teacher & $8(19.9 \%)$ \\
\hline
\end{tabular}

Source: Questionnaire research based on own editing.

Respondents' expectations regarding their studies were also explored to what extent they were met during their current studies. On a Likert scale of 1 to 10, each respondent evaluated two statements that his/her studies would provide a better basis for personal development or starting work. The results of the evaluation are illustrated in Table 4 . The table shows that respondents say their studies provide a reasonable basis for their personal development during the start of their job. Analysis of correlation can demonstrate the existence and the intensity between two or more quantitative variables. Using Pearson's analysis of correlation, we demonstrated the relationship between personal development and work starting variables. The correlation coefficient indicates the intensity and the dependence of relationship during the analysis. The value of the correlation coefficient is $\mathrm{r}=0.641$, which means that there is a stronger than average positive relationship between the two variables examined. A Sig. (2tailed) is $0.000<0.05$, so the significance condition holds, so with a $99.9 \%$ probability level, we can state that there is a correlation between the studies that provide a reasonable basis for personal development and starting work.

Table 4. What expectations do you have for your studies and how well is your program achieving these? (Please rate on a scale of 1 to 10, 1-least affecting, 10-influence the most).

\begin{tabular}{cc}
\hline & Frequency/Percent \\
\hline My study program is a good basis for personal development & $10(20.9 \%)$ \\
My study program is a good basis for starting work & $8,10(23 \%)$ \\
\hline Source: Questionnaire research based on own editing. &
\end{tabular}

The ranking of the most important factors by students in connection with their studies abroad is illustrated in Table 5. For a student in a foreign university environment, the opportunity for personal development and language practice are the key factors that were rated as the highest possible number, i.e., 10. In addition, the quality of education and social integration were also highly rated, as were the services provided by the chosen institution.

Table 5. How important were the following aspects concerning your study abroad? (Please rate on a scale of 1 to 10,1-least affecting, 10-influence the most).

\begin{tabular}{cc}
\hline & Frequency/Percent \\
\hline Personal development & $10(25.9 \%)$ \\
Language improvement & $10(28.4 \%)$ \\
Quality of education & $8(14.7 \%)$ \\
Social integration & $8(16.7 \%)$ \\
Service from host institution & $7(17 \%)$ \\
\hline
\end{tabular}


We performed a linear regression analysis for the variant depending on the multicultural university background in the case of the factors considered important due to studies abroad. The analysis is shown in Table 6 . The coefficient R-value is 0.26 , which is close to 0 , so a weak relationship can be detected. The value of the $\mathrm{R}$ square determination $\mathrm{R}=0.07$ $(7 \%)$, which explains what percentage of the variability of the dependent variable $(Y)$ influences the independent variable $(X)$. Based on the ANOVA table, it can be determined to what extent the regression model describes the data, $\mathrm{F}=4.09, p=0.001$, which satisfies the condition $p<0.05$. The coefficients of the equation of regression are $\mathrm{b} 0=4.81, \mathrm{~b} 1=0.41$.

The equation of regression: $\mathrm{Y}=4.81-0.41 * \mathrm{X}+2.30$.

where: $\mathrm{Y}=$ dependent variable, $\mathrm{X}=$ independent variable, $\mathrm{b} 0=$ the point where the regression line intersects the $X$-axis, $\mathrm{b}=$ the regression coefficient, $\mathrm{e}=$ the standard error of the measurement. The beta of the independent variable $(X)$ is 0.000 . The condition $0.00<0.05$ holds. The $95 \%$ confidence interval values for B $[4.01,5.62]$ indicate where the value of the searched parameter is located. During the study, it becomes clear that there is no linearly regressive relationship between the variables, but in terms of ANOVA and the beta coefficient, a correlation can be detected between the examined dependent and independent variables.

Table 6. Linear Regression analysis.

\begin{tabular}{|c|c|c|c|c|}
\hline & $\mathbf{R}$ & R Square & $\begin{array}{l}\text { Adjusted R } \\
\text { Square }\end{array}$ & $\begin{array}{c}\text { Std. Error of the } \\
\text { Estimate }\end{array}$ \\
\hline \multirow[t]{2}{*}{ ANOVA } & 0.26 & 0.07 & 0.05 & 2.3 \\
\hline & Sum of Squares & df & Mean Square & F Sig. \\
\hline Regression & 108.28 & 5 & 21.66 & $4.090(0.001)$ \\
\hline Residual & 1459.64 & 267 & 5.29 & \\
\hline Total & 1567.91 & 281 & & \\
\hline
\end{tabular}

Source: SPSS database.

Table 7 shows the relationship of students to learning. In connection with the survey, on a Likert scale of 1 to 10, students could rate each statement to what extent they knew themselves. For example, $23 \%$ of respondents believe that they are performance- and success-oriented, so this statement was rated the highest, and $23.4 \%$ strive for knowledge and experience, which was also rated 10. On the other hand, respondents are not forced to learn at all by their family (45\%) and are not demotivated (30.1\%), nor have difficulty in learning (29.85), so these statements were rated the lowest value, 1 . The Cronbach's alpha coefficient value was also determined with the present scale-type question. For the eleven influencing elements examined, the value of Cronbach's alpha coefficient is 0.80, so it is between the two limits, which means that the scale measures satisfactorily.

$17.4 \%$ of respondents have difficulties from moderate to above-average in a multicultural university environment, so the Likert scale was most often rated as 5 and 6, respectively. We perform a one-way analysis of variance concerning the study program and a multicultural university environment. One-way ANOVA analysis was used to perform the study. The statistical test is shown in Table 8. Levene's test (1.45) shows that the standard deviations are homogeneous to perform the ANOVA test. The $p=0.012$, which corresponds to the condition $p<0.05$, so it can be stated that there is a significant difference between the examined groups at the 0.05 significance level. Post hoc analysis was performed using the most stringent Bonferroni test. 
Table 7. What are your attitudes toward learning? (Please rate on a scale of 1 to 10,1 -least affecting, 10-influence the most).

\begin{tabular}{cc}
\hline & Frequency/Percent \\
\hline I'm insecure about myself & $3(13.1 \%)$ \\
I have concentration problem & $1(20.9 \%)$ \\
I'm persistent to the end & $7(17 \%)$ \\
I'm stop in case of failure & $5(14.5 \%)$ \\
I'm studying for grades & $5(17.7 \%)$ \\
I'm performance and success oriented & $10(23 \%)$ \\
I strive for knowledge and experience & $10(23.4 \%)$ \\
My family is forcing me to study & $1(45 \%)$ \\
My perception is difficult, I have a hard time learning & $1(29.8 \%)$ \\
I'm demotivated & $1(30.1 \%)$ \\
I'm lazy & $2(13.8 \%)$ \\
\hline
\end{tabular}

Source: Questionnaire research based on own editing.

Table 8. Test of homogeneity of Variances.

\begin{tabular}{cccccc}
\hline $\begin{array}{c}\text { How Difficult It Is to be } \\
\begin{array}{c}\text { Successful at University in a } \\
\text { Multicultural Environment }\end{array}\end{array}$ & Sum of Squares & Levene & dfatistic & df2 & Sig. \\
\hline ANOVA & 98.14 & 6 & Mean Square & F Sig. \\
Between Groups & 1615.87 & 274 & 16.36 & 2.770 .01 \\
Within Groups & 1714.01 & 280 & & & \\
Total & & & & \\
\hline
\end{tabular}

Source: SPSS database.

Based on the Bonferroni test, it can be stated that in connection with the success in a multicultural university environment, there is a significant difference between students in vocational qualifications and master's degrees $(p=0.027)$, and there is a significant difference between students in bachelor's degrees and master's degrees $(p=0.010)$ at a significance level of 0.05 .

\subsection{Hypothesis Testing}

For each hypothesis related to the topic of study, we assigned an alternative hypothesis of $\mathrm{H} 0$, which is confirmed in case primary hypotheses $\mathrm{H} 1$ and $\mathrm{H} 2$ are rejected. One-way analysis of variance is used to test the hypotheses. One-way ANOVA analysis shows whether a non-metric independent variable influences a metric-dependent variable. In the first hypothesis, we show to what extent the multicultural studies of females and males contribute to a successful start of work. To test Hypothesis $\mathrm{H} 1$, we analyzed variance using a One-Way ANOVA. Based on Levene's test (0.37), the variances are homogeneous, so we can study ANOVA. The value of $p$ is 0.717 , so it is close to 1 . Therefore, it can be said that the multicultural studies of females and males create a reasonable basis for starting work. It is not necessary to perform a post hoc test. Therefore, hypothesis $\mathrm{H} 1$ is accepted while $\mathrm{H} 0$ is rejected. Examination of the second hypothesis reveals how the multicultural studies of females and males almost contribute to their personal development. We also use analysis of variance, i.e., One-Way ANOVA, to test Hypothesis H2. Based on Levene's test (0.30), the variances are homogeneous, so the ANOVA test can be performed. The value of $p$ is 0.508 , i.e., above $50 \%$, suggesting that their multicultural studies provide an adequate basis for their personal development for females and males. Therefore, it is not necessary to perform a post hoc test. Hypothesis $\mathrm{H} 2$ is confirmed, so alternative hypothesis $\mathrm{H} 0$ is rejected. 


\section{Discussion}

The results obtained during the evaluation of data from quantitative research can be brought in line with the results of previous research in this field. The results obtained in testing the hypotheses would support what has been read in the literature.

Based on the aggregated responses of the participants in the research and the hypothesis test, it can be said that their studies provide a reasonable basis for entering the labor market. Furthermore, Krishnamurthi [10] and Popov et al. [55] also emphasize the relevance of the knowledge and competencies available in multicultural higher education with regard to emergence in the labor market.

Moreover, in connection with our hypothesis testing, we have shown that students have a similarly good basement for their personal development. Our research results can be supported by Gay [56] and Yusupova et al. [57]; in addition to the importance of the contribution of studies to professional development, personal development is equally emphasized [58]. Derényi [30] similarly agrees that with the internationalization of higher education, students can learn the competencies they need for their studies and their future work. Finally, we examined the correlations between personal development and work-start variables with a statistical test as a control. Using Pearson's correlation analysis, we have shown a correlation between studies that provide a reasonable basis for starting work and personal development, so they are not mutually exclusive.

Sahal et al. [37] mention in their study that, according to the psychological interpretation of multiculturalism, it promotes the possibility of personal development, which we can also bring in line with the results presented in our research. In connection with our Likertscale question, we showed that among students, in addition to a flexible schedule, the possibility of personal development was the most influencing factor of their studies. Our next question also confirmed that students consider the possibility of personal development to be the most important factor when receiving education abroad.

Our research also assessed the advantages and disadvantages of multicultural education among students. In his work, Bakhov [59] discusses the list of these advantages and disadvantages. He mentions the different ways of life as a significant negative, which can also be supported by the evaluation obtained in our study. The opinion of the students completing the questionnaire also reflects that the most significant disadvantage of multicultural education is the conflicting value system, which also covers the lifestyle. Smith et al. [35] suggests that multicultural education contributes to broad and recent sharing of knowledge. The most significant benefit of multicultural education among students is sharing knowledge, experience, and expertise, so we could show results in line with the literature. M. Császár et al. [60] also emphasizes in their 2021 study that the acquisition, distribution, and application of knowledge is a key factor in increasing the productivity in any area of life. In addition, multicultural education enhances individual creativity while language skills can be developed. Wang similarly explains in his 2005 study [61] that communication provides an excellent opportunity to understand differences between people, and that increased creativity provides a more open perception for the individuals.

The diverse student base of Hungarian universities and the spectrum of multicultural education have become more and more noticeable over the years. One of the main reasons for this is the acquisition of recent knowledge. Kéri [32] explains in her study that most students receive full-time and undergraduate training during their mobility, according to the situation in our case.

\section{Conclusions}

The source of the conclusions drawn from this study is the database of the questionnaire survey. The most basic conclusions of the research were formulated during the compilation and evaluation of the data and the testing of the established hypotheses. Three-quarters of the students had already worked before their university studies and managed to gain experience in the labor market, according to which they can make better use of their university studies by combining the experience gained during the work. It is an 
excellent opportunity to have a high chance of success in the future. The feedback reflects that students' studies are mainly influenced by the flexible schedules, the opportunities for personal development, and the effects of stress. In connection with their studies abroad, they regard their personal development and the possibility of language practice. Students' attitudes towards learning are characterized by the performance and success orientation and the accumulation of knowledge and experience. Therefore, they are determined and strive to achieve their future goals. The program of study pursued by students advances them to a similar extent in their personal development and provides an equally good basement for starting work. Beside the curriculum to be acquired, several internships may take place in the institutions of higher education, where possible, which would serve as a kind of basement for young graduates. Students regard intercultural education as a fantastic opportunity to share their ideas, knowledge, and experiences while learning different traditions and building international relationships, and that can even lead to close friendships. Teaching in diverse settings is a tremendous experience for students and teachers as well over which they provide insight into each other's cultural world and thus work together with joint strength and understanding. In addition, they can get a taste of the education and upbringing system of the opposing culture and apply new methods to traditional technologies in both teaching and learning. Cultural diversity makes people much more innovative, creative, and open and radically transforms their thinking. They accept each other without stumbling into prejudice or looking down on each other for some reason. The quality and consequences of cooperation are not a matter of culture but rather a matter of individual attitude. Flexible adaptation and values brought from home greatly influence attitudes towards the unknown factor from the individual's point of view. However, a familiar voice can be reached in almost every culture with the investment of proper benevolence and of energy of sufficient grade and quality. Although it is not easy for students to succeed in a university of multicultural environment, they have a favorable view of cultural diversity and see many valuable opportunities for both the university and the students.

Author Contributions: All authors participated in the theoretical framework, data collection and analysis, discussion and conclusions. All authors have read and agreed to the published version of the manuscript.

Funding: This research received no external funding.

Institutional Review Board Statement: This research was approved by the Institutional Review Board at J. Selye University (protocol number IRB-1-2021).

Informed Consent Statement: All students agreed to participate at the beginning of the research.

Data Availability Statement: The data presented in this study are available on request from the corresponding author.

Conflicts of Interest: The authors declare no conflict of interest.

\section{References}

1. Bíró, A.; Kovács, P. Diversity in Action Local Public Management of Multi-Ethnic Communities in Central and Eastern Europe. Arktisz Studio Bp. 2001, 390, 191.

2. Portugal, L. Diversity Leadership in Higher Education. Acad. Leadersh. J. 2006, 4, 2.

3. Nieto, S. Re-imagining multicultural education: New visions, new possibilities. Multicult. Educ. Rev. 2017, 9, 1-10. [CrossRef]

4. Ostrosky-Solis, F.; Ramirez, M.; Ardila, A. Effects of Culture and Education on Neuropsychological Testing: A Preliminary Study with Indigenous and Nonindigenous Population. Appl. Neuropsychol. 2010, 11, 186-193. [CrossRef]

5. Johnson, J.R.; McIntosh, A.S. Toward a Cultural Perspective and Understanding of the Disability and Deaf Experience in Special and Multicultural Education. Remedial Spec. Educ. 2008, 30, 67-83. [CrossRef]

6. Rosselli, M.; Ardila, A. The impact of culture and education on non-verbal neuropsychological measurements: A critical review. Brain Cogn. 2003, 52, 326-333. [CrossRef]

7. Yanniris, C. Education for Sustainability, Peace, and Global Citizenship: An Integrative Approach. Educ. Sci. 2021, 11, 430. [CrossRef] 
8. Byker, E.J.; Marquardt, S.K. Using Critical Cosmopolitanism to Globally Situate Multicultural Education in Teacher Preparation Courses. J. Soc. Stud. Educ. Res. 2016, 7, 1-21.

9. Rosado, C. Toward a Definition of Multiculturalism. 1996. Available online: https://www.academia.edu/777187/Toward_a_ Definition_of_Multiculturalism (accessed on 7 January 2022).

10. Krishnamurthi, M. Assessing Multicultural Initiatives in Higher Education Institutions. Assess. Eval. High. Educ. 2003, 28, 263-277. [CrossRef]

11. Kumi-Yeboah, A.; James, W.B. The Relevance of Multicultural Education for Adult Learners in Higher Education. Int. Forum Teach. Stud. 2011, 7, 10-16.

12. Aydin, H. Multicultural Education Curriculum Development in Turkey. Mediterr. J. Soc. Sci. 2012, 3, 277.

13. Özturgut, O. Understanding Multicultural Education. Curr. Issues Educ. 2011, 14, 1-21.

14. Tonbuloglu, B.; Aslan, D.; Aydin, H. Teacher's Awareness of Multicultural Education and Diversity in School Settings. Eurasian J. Educ. Res. 2016, 64, 1-28. [CrossRef]

15. Dür, M.; Keller, L. Education for Sustainable Development through International Collaboration. A Case Study on Concepts and Conceptual Change of School-Students from India and Austria on Gender Equality and Sustainable Growth. Educ. Sci. 2018, 8, 187. [CrossRef]

16. Alghamdi, Y. Multicultural Education in the US: Current Issues and Suggestions for Practical Implementations. Int. J. Educ. 2017, 9, 44-52. [CrossRef]

17. Sharma, S. Multicultural Education: Teachers' Perceptions and Preparations. J. Coll. Teach. Learn. 2005, 2, 53-64. [CrossRef]

18. Doucette, B.; Sanabria, A.; Sheplak, A.; Aydin, H. The Perceptions of Culturally Diverse Graduate Students on Multicultural Education: Implication for Inclusion and Diversity Awareness in Higher Education. Eur. J. Educ. Res. 2021, 10, 1259-1273. [CrossRef]

19. Erbas, Y.H. A Qualitative Case Study of Multicultural Education in Turkey: Definitions of Multiculturalism and Multicultural Education. Int. J. Progress. Educ. 2019, 15, 23-43. [CrossRef]

20. Rachmawati, Y.; Yi-Fong, P.; Chen, H. The Necessity of Multicultural Education in Indonesia. Int. J. Educ. Res. 2014, 2, 317-328.

21. Soares, F.; Sudarsana, K. Religious Harmony Among Senior High School Students Multicultural Education Case Study in the Cova-Lima District of East Timor. Vidyottama Sanatana Int. J. Hindu Sci. Relig. Stud. 2018, 2, 154-162.

22. Aktoprak, A.; Yigit, P.; Güneyli, A. Attitudes of primary school teachers toward multicultural education. Qual. Quant. 2017, 52, 181-194. [CrossRef]

23. Šenšelová, I. Multikultúrna Výchova v Predprimárnom Vzdelávaní; Metodicko-Pedagogické Centrum: Bratislava, Slovakia, 2014.

24. Blue, C.; Mupinga, D.; Ernst, J.V.; Clark, A.C.; DeLuca, V.W.; Kelly, D. Multiculturalism in the Classroom. Technol. Eng. Teach. 2018, 77, 25-31.

25. Kashkan, G.V.; Egorova, M.S. Problems and outlooks of international integration of higher education. Int. Educ. Stud. 2015, 8, 250-255. [CrossRef]

26. Korol, L.; Goncalves, G.; Cabral, M. The impact of multicultural personality on tolerance of diversity in a sample of Portuguese university students. Teor. E Pract. 2016, 18, 57-74. [CrossRef]

27. Kahraman, P.B.; Sezer, G.O. Relationship between Attitudes of Multicultural Education and Perceptions Regarding Cultural Effect of Globalization. Eurasian J. Educ. Res. 2017, 16, 233-249.

28. Kőmíves, P.M. A felsőoktatás nemzetköziesedésének történelmi vetületei, mint az innováció és a tudásáramlás történelmi példái Historical Aspects of the Internationalisation of the Higher Education as Historical Examples of Innovation and Knowledge Transfer. Int. J. Eng. Manag. Sci. (IJEMS) 2020, 5, 87-97. [CrossRef]

29. Dinya, L. A perspective on the Hungarian higher education system: Challenges and dilemmas. EAIE Conference Conversation Starter 3: Stepping into a new era: New voices and perspectives on Central and Eastern European higher education. In Proceedings of the European Association for International Education, Prague, Czech Repubic, 16-19 September 2014; Anna Glas, European Association for International Education: Amsterdam, The Netherlands, 2014; pp. 23-28.

30. Derényi, A. A Mozgás Tere A Magyar Felsőoktatás és a Nemzetközi Mobilitási Folyamatok Campus Hungary Tanulmánykötet; Balassi Intézet: Budapest, Hungary, 2014; p. 238.

31. Wusching, Á.T. A nemzetközi hallgatók tanulmányi célú mobilitásának jellegzetességei Pécs és Debrecen példáján International students' educational mobility through the examples of Pécs and Debrecen. Tér És Társadalom 2017, 31, 69-82. [CrossRef]

32. Kéri, A. A magyar felsőoktatásban tanuló külföldi hallgatók motivációjának vizsgálata. E-CONOM Online Sci. J. 2016, 5, 36-50. [CrossRef]

33. Simai, M. A felsőoktatás jövője, az élethosszi tanulás és a globális kihívások Future of Higher Education, Life-Long Learning and Global Challenges. Magy. Tudomány 2018, 179, 90-98. [CrossRef]

34. Watkins, M.; Lean, G.; Noble, G. Multicultural education: The state of play from an Australian perspective. Race Ethn. Educ. 2016, 19, 46-66. [CrossRef]

35. Smith, T.B.; Constantine, M.G.; Dunn, M.G.; Dinehart, T.W.; Montoya, J.M.; Jared, A. Multicultural education in the mental health profession: A meta-analytic review. BYU Sch. Arch. Cit. 2006, 53, 132-145. [CrossRef]

36. Accuff, J.B. Discursive underground: Re-transcribing the history of art education using critical multicultural education. Vis. Inq. 2013, 2, 219-231. [CrossRef] 
37. Sahal, M.; Musadad, A.A.; Akhyar, M. Tolerance in Multicultural Education: A Theoretical Concept. Int. J. Multicult. Multirelig. Underst. 2018, 5, 115-122. [CrossRef]

38. Holm, G.; Zilliacus, H. Multicultural education and intercultural education: Is there a difference? In Dialogs on Diversity and Global Education; Talib, M., Loima, J., Paavola, H., Patrikainen, S., Eds.; Peter Lang: New York, NY, USA, 2009; pp. 11-28.

39. Meier, K.S. Factors Influencing the Institutionalization of Diversity in Higher Education. Ph.D. Thesis, Minnesota State University Mankato, Mankato, MI, USA, 2012.

40. Forest, J.; Lean, G.; Dunn, K. Challenging racism through schools: Teacher attitudes to cultural diversity and multicultural education in Sydney, Australia. Race Ethn. Educ. 2015, 19, 618-638. [CrossRef]

41. Cherng, H.S.; Davis, L.A. Multicultural Matters: An Investigation of Key Assumptions of Multicultural Education Reform in Teacher Education. J. Teach. Educ. 2017, 70, 219-236. [CrossRef]

42. Gardner, R.; Karakasoglus, Y.; Luchtenberg, S. Islamophobia in the Media A Response from Multicultural Education. Intercult. Educ. 2008, 19, 119-136. [CrossRef]

43. Polat, S.; Arslan, Y.; Dincer, O. Diversity leadership skills of school administrators: A scale development study. Issues Educ. Res. 2017, 27, 512-526

44. Hidayat, Y.A. Graduates' employability skills in business management and success initial career. Acta Oeconomica Univ. Selye 2019, 8, 77-90.

45. Huda, M.; Mustafa, M.C.; Mohamed, A.K. Understanding of Multicultural Sustainability through Mutual Acceptance: Voices from Intercultural Teachers' Previous Early Education. Sustainability 2021, 13, 5377. [CrossRef]

46. Catarci, M. Intercultural Education and Sustainable Development. A Crucial Nexus for Contribution to the 2030 Agenda for Sustainable Development. Soc. Sci. 2021, 10, 24. [CrossRef]

47. Nayir, K.F.; Çetin, S.K. Multicultural education and democracy according to university students. Akdeniz Educ. Res. J. 2018, 12, 229-252.

48. Sá, M.J.; Serpa, S. Cultural Dimension in Internationalization of the Curriculum in Higher Education. Educ. Sci. 2020, 10, 375 [CrossRef]

49. Murray, N. Understanding Student Participation in the Internationalised University: Some Issues, Challenges, and Strategies. Educ. Sci. 2018, 8, 96. [CrossRef]

50. Banks, J.A. An Introduction to Multicultural Education, 6th ed.; Pearson Education, University of Washington: Seattle, WA, USA, 2017

51. Agirdag, O.; Merry, M.S.; Van Houtte, M. Teachers' Understanding of Multicultural Education and the Correlates of Multicultural Content Integration in Flanders. Educ. Urban Soc. 2014, 48, 556-582. [CrossRef]

52. Jayakumar, U. Can higher education meet the needs of an increasingly diverse and global society? Campus diversity and cross-cultural workforce competencies. Harv. Educ. Rev. 2018, 78, 615-651. [CrossRef]

53. Wawrosz, P.; Jurásek, M. Developing Intercultural Efficiency: The Relationship between Cultural Intelligence and Self-Efficacy. Soc. Sci. 2021, 10, 312. [CrossRef]

54. Portuguez Castro, M.; Gómez Zermeño, M.G. Identifying Entrepreneurial Interest and Skills among University Students Sustainability 2021, 13, 6995. [CrossRef]

55. Popov, V.; Brinkman, D.; Biemans, H.J.A.; Mulder, M.; Kuznetsov, A.; Noroozi, O. Multicultural student group work in higher education An explorative case study on challenges as perceived by students. Int. J. Intercult. Relat. 2012, 36, 302-317. [CrossRef]

56. Gay, G. The Importance of Multicultural Education. Educ. Leadersh. 2004, 61, 30-35.

57. Yusupova, G.F.; Podgorecki, J.; Markova, N.G. Educating Young People in Multicultural Educational Environment of Higher Education Institution. Int. J. Environ. Sci. Educ. 2015, 10, 561-570.

58. Burkšaitienè, N.; Lesčinskij, R.; Suchanova, J.; Šliogerienė, J. Self-Directedness for Sustainable Learning in University Studies: Lithuanian Students' Perspective. Sustainability 2021, 13, 9467. [CrossRef]

59. Bakhov, I.S. Dialogue of Cultures in Multicultural Education. World Appl. Sci. J. 2014, 29, 106-109.

60. Császár, Z.M.; Teperics, K.; Köves, K. Nemzetközi hallgatói mobilitás a Magyar felsőoktatásban International student mobility in Hungarian higher education. Mod. Geográfia 2021, 16, 67-86. [CrossRef]

61. Wang, H. Aporias, Responsibility, and the Im/Possibility of Teaching Multicultural Education. Educ. Theory 2005, 55, 45-59. [CrossRef] 